Abstracta Iranica Abstracta Iranica

Revue bibliographique pour le domaine irano-aryen

Volume 30 | 2010

Comptes rendus des publications de 2007

\title{
Rome and Persia in Late Antiquity. Neighbours and Rivals. Cambridge, Cambridge University Press, 2007, xvi, 347 p.
}

Christelle Jullien

\section{(2) OpenEdition \\ 1 Journals}

Édition électronique

URL : http://journals.openedition.org/abstractairanica/37878

DOI : 10.4000/abstractairanica.37878

ISSN : 1961-960X

Éditeur :

CNRS (UMR 7528 Mondes iraniens et indiens), Éditions de l'IFRI

Édition imprimée

Date de publication : 8 avril 2010

ISSN : 0240-8910

Référence électronique

Christelle Jullien, «Rome and Persia in Late Antiquity. Neighbours and Rivals. Cambridge, Cambridge University Press, 2007, xvi, 347 p. », Abstracta Iranica [En ligne], Volume 30 | 2010, document 203, mis en ligne le 08 avril 2010, consulté le 26 septembre 2020. URL : http://journals.openedition.org/ abstractairanica/37878; DOI : https://doi.org/10.4000/abstractairanica.37878

Ce document a été généré automatiquement le 26 septembre 2020.

Tous droits réservés 


\title{
Rome and Persia in Late Antiquity. Neighbours and Rivals. Cambridge, Cambridge University Press, 2007, xvi, $347 \mathrm{p}$.
}

\author{
Christelle Jullien
}

1 Il s'agit de la traduction anglaise du livre paru en 2001 sous le titre Rom und das Perserreich. Zwei Weltmächte zwischen Konfrontation und Koexistenz, Berlin (coll. Studienbücher. Geschichte und Kultur der Alten Welt).

2 Les AA., suivant l'ordre chronologique des événements politico-militaires qui ont marqué les relations romano-perses, ont eu soin d'intégrer un corpus significatif de textes venant illustrer le propos. Plusieurs chapitres sont dévolus aux régions limitrophes et royaumes vassaux: Hatra, Palmyre, Hira, Arménie. Un chapitre est consacré aux relations entre chrétiens et zoroastriens; là encore, cette synthèse est agrémentée d'extraits choisis de sources. L'ouvrage s'achève par deux exposés, l'un sur le concept de "famille royale » et de "légitimité ", l'autre sur les échanges culturels entre les deux empires. Cet aspect est surtout traité en fonction des liens d'ambassade, d'espionnage, mais aussi à travers les multiples déportations de prisonniers sur les sols perse et romain. Plusieurs appendices peuvent être utiles (liste des souverains sassanides, chronologie, glossaire).

\section{INDEX}

Thèmes : 6.3. Autres religions 
AUTEURS

CHRISTELLE JULLIEN

CNRS/Mondes iranien et indien - Paris 